\title{
Sosialisasi Pembuatan Virgin Coconut Oil Sebagai Suplemen Peningkat Imunitas Untuk Menghadapi Covid-19
}

\author{
Rosidah*, Effendy De Lux Putra, Panal Sitorus, Denny Satria, Mahatir Muhammad, \\ M. Fauzan Lubis \\ Fakultas Farmasi, Universitas Sumatera Utara \\ email: rosidah@usu.ac.id
}

\begin{abstract}
This community service aims to provide knowledge about the manufacture of Virgin Coconut Oil simply and provide the knowledge that Virgin Coconut Oil in improving body immunity to handle or prevent the development of covid-19 positive patients. Through community service activities aimed at the community in Johor Building Village, Medan Johor Sub-District, Medan. Public Understanding of the benefits and content of VCO, as well as the correct way of making VCO, simple and while paying attention to the quality of Virgin Coconut Oil homemade seen based on physical quality includes colors, smells and flavors produced by homemade VCO and VCO from Palm Mustika which is normal for smell and taste and white to pale yellow. The chemical quality of homemade VCO dominated by lauric acid is 53.2\%, VCO from Mustika Palem is 49.4\%. homemade VCO free fatty acids (FFA) are 0.38\% while VCO Mustika Palem free fatty acids (FFA) are 0.08\%, the number of homemade VCO peroxides is 0.06 meq $/ \mathrm{kg}$ while the number of peroxide VCO Mustika Palem is 0.00 meq/kg and the homemade VCO saponification number is $252.74 \mathrm{mg} \mathrm{KOH/gram} \mathrm{while} \mathrm{the} \mathrm{number} \mathrm{of}$ VCO Mustika Palem is $253.13 \mathrm{mg} \mathrm{KOH/gram}$
\end{abstract}

Keywords: Gedung Johor, Service, Training, VCO

\section{Abstrak}

Pengabdian kepada masyarakat ini bertujuan untuk memberikan pengetahuan mengenai pembuatan Virgin Coconut Oil secara sederhana dan memberikan pengetahuan bahwa Virgin Coconut Oil dalam meningkatkan imunitas tubuh sehingga dapat menangani atau mencegah semakin berkembangnya pasien positif Covid-19. Melalui kegiatan pengabdian kepada masyarakat yang ditujukan kepada masyarakat di Kelurahan Gedung Johor, Kecamatan Medan Johor, Medan. Pemahaman masyarakat terhadap manfaat dan kandungan VCO serta cara pembuatan VCO yang benar, sederhana dan dengan tetap memperhatikan kualitas dari VCO yang dibuat, dilihat berdasarkan mutu fisik meliputi warna, bau dan rasa yang dihasilkan VCO buatan sendiri dan VCO dari Palm Mustika yaitu normal untuk bau dan rasa serta berwarna putih hingga kuning pucat. Mutu kimia VCO buatan sendiri yang didominasi asam laurat yaitu 53,2\% sedangkan VCO dari Mustika Palem yaitu 49,4\%. asam lemak bebas (FFA) VCO buatan sendiri yaitu 0,38\% sedangkan asam lemak bebas (FFA) VCO Mustika Palem yaitu 0,08\%, bilangan peroksida VCO buatan sendiri yaitu 0,06 meq/kg sedangkan bilangan peroksida VCO Mustika Palem yaitu 0,00 meq/kg dan bilanga penyabunan VCO buatan sendiri yaitu 252,74 mg KOH/gram sedangkan bilangan penyabunan VCO Mustika Palem yaitu 253,13 mg $\mathrm{KOH} / \mathrm{gram}$.

Kata Kunci: Gedung Johor, Pengabdian, Pelatihan, VCO

\section{PENDAHULUAN}

Corona Virus Disease 2019 (COVID19) merupakan penyakit yang disebabkan oleh severe acute respiratory syndrome coronavirus 2 (SARS-Cov-2). Sars-Cov-2 ditularkan melalui kontak langsung dengan penderita, droplet yang dikeluarkan penderita ketika batuk/bersin, 
serta tangan yang menyentuh mulut, hidung dan mata setelah menyentuh benda- benda yang terkontaminasi virus tersebut. Berdasarkan studi epidemiologi, masa inkubasi COVID-19 beragam, dengan rentang antara 1 hingga 14 hari, dan secara umum dalam 3 sampai 7 hari $\left(\mathrm{WHO}^{\mathrm{a}}, 2020 ; \mathrm{CDC}, 2020 ; \mathrm{WHO}^{\mathrm{b}}, 2020\right)$.

Jumlah kasus positif COVID-19 di Indonesia terus meningkat. Presiden Republik Indonesia telah membentuk Gugus Tugas Percepatan Penanganan COVID-19 melalui Keputusan Presiden Nomor 9 Tahun 2020 tentang Perubahan atas Keputusan Presiden Nomor 7 Tahun 2020 tentang Gugus Tugas Percepatan Penanganan COVID-19, dengan Kepala Badan Nasional Penanggulangan Bencana (BNPB) sebagai Ketua Pelaksana (NHC, 2020; $\mathrm{WHO}^{\mathrm{c}}, 2020$ ).

Kota Medan sampai saat ini dilaporkan terdapat jumlah pasien positif sebanyak 86 orang, dengan jumlah pasien yang meninggal sebanyak 9 orang, 84 orang pasien dalam pemantauan dan yang sembuh sebanyak 16 orang dimana Kecamatan dengan status zona merah adalah Kecamatan Medan Sunggal, Kecamatan Medan Johor, Kecamatan Medan Selayang, Kecamatan Medan Tuntungan, Kecamatan Medan Amplas, Kecamatan Medan Denai dan Kecamatan Medan Kota dimana jumlah pasien Positif dan dalam pemantauan berjumlah $>10$ orang (Pemkomedan, 2020).

Saat ini belum terdapat terapi atau pengobatan spesifik untuk COVID-19. Namun demikian, beberapa obat yang potensial telah dipergunakan untuk penderita COVID-19, walaupun masih dalam status obat uji dan hasilnya menunjukkan efektivitas yang baik.

Minyak kelapa murni (Virgin Coconut Oil = VCO) merupakan produk kelapa berkualitas tinggi yang menjadi produk andalan di negara-negara penghasil kelapa. VCO ketika digunakan secara topikal berfungsi sebagai pelindung kulit dan mencegah infeksi, melindungi kulit dari radikal bebas dan melembabkan. VCO mengandung fitosterol sebagai antiinflamasi. Minyak kelapa merupakan trigliserida yang tidak memiliki aktivitas antimikroba dan antivirus serta mampu meningkatkan imunitas dengan meningkatkan level CD4+ (Bawalan \& Chapman, 2006).

Karena hal tersebut diatas, maka perlu untuk melakukan sosialisasi pembuatan Virgin Coconut Oil dan penggunaannya untuk meningkatkan imunitas dalam menghadapi pandemic Covid-19. Dalam hal ini, mitra yang terlibat dalam pengabdian kepada masyarakat adalah masyarakat di Kelurahan Gedung Johor, Kecamatan Medan Johor, Medan.

\section{METODE PENGABDIAN}

Kegiatan pengabdian kepada masyarakat ini merupakan pemberian pelatihan cara pembuatan Virgin Coconut Oil (VCO) dan sosialisasi manfaat penggunaan VCO untuk meningkatkan imunitas tubuh untuk menghadapi pandemic Covid-19. Metode ini merupakan metode kegiatan pelatihan yang melibatkan 30 masyarakat di Kelurahan Gedung Johor, Kecamatan Medan Johor, Kota Medan untuk dapat membuat VCO dengan Teknik yang sederhana dan memperoleh pengetahuan pengaruh VCO dalam meningkatkan imunitas tubuh

Kegiatan ini dilakukan dalam 2 (dua) kali kunjungan kepada mitra. Pemberian materi dan praktik pembuatan VCO dilakukan pada kunjungan pertama dan sosialisasi manfaat VCO dalam meningkatkan imunitas serta evaluasi pembuatan VCO dilakukan pada kunjungan kedua.

\section{A. Prosedur Kegiatan}

1. Pembuatan VCO dilakukan dengan cara memarut kelapa yang telah tua kemudian dibuat santan kelapa dengan perbandingan $1 \mathrm{~kg}$ kelapa ditambahkan 
$1 \mathrm{~L}$ akuades dan didiamkan selama 2 jam untuk mendapatkan 2 lapisan yaitu lapisan krim kelapa dan skim kelapa,

2. Bagian krim kelapa diambil dan ditambahkan ragi sebanyak $4 \mathrm{~g}$ dari santan yang digunakan dan diinkubasi selama 24 jam pada wadah tertutup.

3. Terbentuk 3 lapisan yaitu lapisan atas merupakan $8 \mathrm{VCO}$, lapisan tengah merupakan blondo (ampas krim) dan lapisan bawah merupakan air. VCO dipisahkan dengan menggunakan Teknik penyaringan dan VCO yang diperoleh dimasukkan kedalam botal dan dilakukan analisis asam lemak penyusun dan sifat fisiko kimia.

\section{B. Penampakkan Fisik}

VCO dihasilkan dengan bantuan papain kemudian diamati aroma/bau, rasa, dan warna sesuai dengan Standar Nasional Indonesia (SNI) 7381:2008 (Standar Nasional Indonesia (SNI), 2008) mengenai keadaan VCO.

\section{Bilangan Asam}

Bilangan asam pada VCO dapat dinyatakan sebagai \% FFA yang ditentukan sesuai dengan prosedur Standar Nasional Indonesia (SNI) 661:2009 (Standar Nasional Indonesia (SNI), 2009) mengenai penentuan asam lemak bebas pada VCO. \% FFA rata-rata dalam percobaan ini dilakukan sebanyak sebanyak tiga kali.

\section{Bilangan Peroksida}

Bilangan peroksida pada VCO ditentukan sesuai dengan Standar Nasional Indonesia (SNI) 3960:2017 (Standar Nasional Indonesia (SNI), 2017) mengenai penentuan bilangan peroksida pada VCO Bilangan peroksida adalah indeks jumlah lemak atau minyak yang telah mengalami oksidasi. Angka peroksida sangat penting untuk identifikasi tingkat oksidasi minyak. Sebanyak $5 \mathrm{~mL}$ sampel VCO dimasukkan ke dalam erlenmeyer $250 \mathrm{~mL}$, kemudian ditambahkan $15 \mathrm{~mL}$ campuran pelarut yang terdiri dari $60 \%$ asam asetat glasial dan $40 \%$ kloroform. Setelah minyak larut, ditambahkan 0,5 g KI sambil dikocok kemudian didiamkan selama 30 menit dalam tempat gelap. Setelah itu ditambahkan $15 \mathrm{~mL}$ aquades. Ditambahkan $0.5 \mathrm{~mL}$ larutan pati $1 \%$. Titrasi dengan larutan $0,1 \quad \mathrm{~N} \quad \mathrm{Na}_{2} \mathrm{~S}_{2} \mathrm{O}_{3}$ sampai warna biru mulai hilang. Hasilnya dinyatakan dalam miliekuivalen per 1000 g minyak.

\section{E. Bilangan Penyabunan}

Bilangan penyabunan pada VCO ditentukan sesuai dengan Standar Nasional Indonesia (SNI) 3657:2012 (Standar Nasional Indonesia (SNI), 2012) mengenai penentuan bilangan penyabunan pada VCO, mengenai pembakuan larutan standar sekunder $\mathrm{HCl}$, titrasi larutan blanko, serta penentuan bilangan penyabunan pada VCO. KOH dimasukkan ke dalam erlenmeyer $250 \mathrm{~mL}$ yang bertutup kemudian ditambahkan $1 \mathrm{~g}$ sampel. Campuran ditutup rapat, didiamkan, kemudian direfluks selama 30 menit pada suhu $70^{\circ} \mathrm{C}$ hingga tidak terlihat butiran lemak/minyak di dalam larutan. Campuran larutan kemudian didinginkan dan ditambahkan 2-3 tetes indikator metil merah, selanjutnya dititrasi dengan menggunakan larutan $\mathrm{HCl}$ hingga larutan berubah warna dari kuning menjadi merah (dilakukan tiga kali pengulangan).

\section{F. Analisa Asam Lemak dalam Virgin Coconout Oil (VCO) dengan Gas Chromatography}

Sampel diinjeksikan melalui suatu sampel injection port yang temperaturnya dapat diatur, senyawa-senyawa dalam sampel akan menguap dan akan dibawa oleh gas pengemban menuju kolom. Zat terlarut akan teradsorpsi pada bagian atas kolom oleh fase diam, kemudian akan merambat dengan laju rambatan masing-masing komponen yang sesuai dengan nilai $\mathrm{Kd}$ 
masing-masing komponen tersebut (Khopkar, 1990).

Komponen-komponen tersebut terelusi sesuai dengan urut-urutan makin besarnya nilai koefisien partisi (Kd) menuju ke detektor. Detektor mencatat sederetan sinyal yang timbul akibat perubahan konsentrasi dan perbedaan laju elusi. Pada alat pencatat sinyal ini akan tampak sebagai kurva antara waktu terhadap komposisi aliran gas pembawa.

\section{HASIL DAN PEMBAHASAN} \begin{tabular}{llr}
\multicolumn{2}{c}{ Kegiatan pengabdian } & kepada \\
masyarakat ini bertujuan & untuk \\
memberikan pengetahuan mengenai
\end{tabular} pembuatan Virgin Coconut Oil secara sederhana dan memberikan pengetahuan bahwa Virgin Coconut Oil dalam meningkatkan imunitas tubuh sehingga dapat menangani atau mencegah semakin berkembangnya pasien positif Covid-19. Melalui kegiatan pengabdian kepada masyarakat yang ditujukan kepada masyarakat di Kelurahan Gedung Johor, Kecamatan Medan Johor, Medan.

Respon peserta pun lebih besar pada pelatihan pembuatan VCO. Pelatihan ini perlu dilakukan karena keberhasilan produk VCO sangat ditentukan oleh beberapa faktor seperti sterilitas alat dan bahan, suhu, waktu inkubasi dan ketelitian pengambilan lapisan minyak VCO. Sterilitas bahan dan alat penting karena proses pembuatan VCO merupakan fermentasi. Jadi dengan menjaga sterilitas bahan dan alat, tidak ada bakteri atau pun kontaminan lain yang hidup dalam santan. Kandungan kimia pada daging kelapa adalah air, protein, dan lemak. Santan kelapa yaitu cairan yang berwarna putih yang diperoleh dari pemerasan. Jika santan didiamkan akan terpisah menjadi dua fase yaitu fase skim yang jernih bagian bawah dan fase krim yang berwarna putih susu di bagian atas.

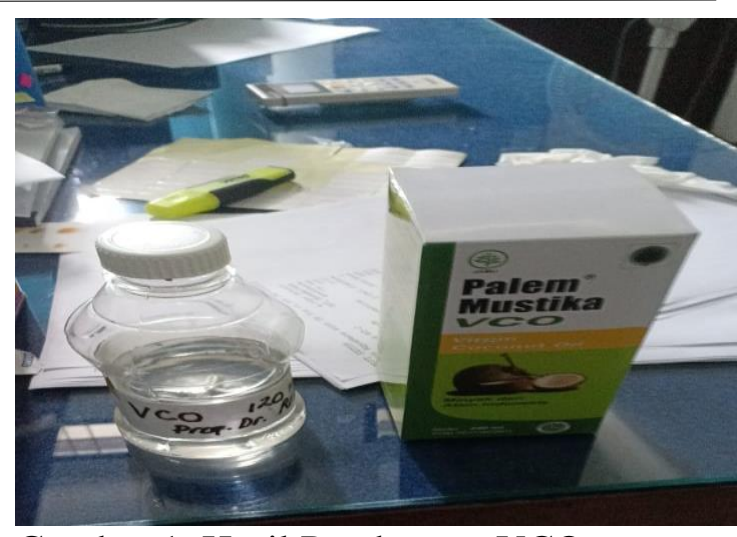

Gambar 1. Hasil Pembuatan VCO

Tabel 1. Hasil Analisis VCO (Mustika Palem) dengan Gas Chromatography

\begin{tabular}{|l|l|}
\hline \multicolumn{1}{|c|}{ Parameter } & \multicolumn{1}{c|}{ Hasil } \\
\hline Asam lemak bebas & $0,08 \%$ \\
\hline Peroksida & $0,00 \mathrm{meq} / \mathrm{kg}$ \\
\hline Saponifikasi & $\begin{array}{l}253,13 \mathrm{mg} \\
\text { KOH/gram }\end{array}$ \\
\hline Kaprilat (C8) & $10,0 \%$ \\
\hline Kaprat (C10) & $6,4 \%$ \\
\hline Laurat $(\mathrm{C} 12)$ & $49,4 \%$ \\
\hline Miristat $(\mathrm{C} 14)$ & $16,7 \%$ \\
\hline Palmitat $(\mathrm{C} 16)$ & $8,0 \%$ \\
\hline Stearat $(\mathrm{C} 18)$ & $1,9 \%$ \\
\hline Oleat $(\mathrm{C} 18: 1)$ & $6,3 \%$ \\
\hline Linoleat $(\mathrm{C} 18: 2)$ & $1,1 \%$ \\
\hline
\end{tabular}

Tabel 2. Hasil Analisis VCO (Buatan) dengan Gas Chromatography

\begin{tabular}{|l|l|}
\hline \multicolumn{1}{|c|}{ Parameter } & \multicolumn{1}{c|}{ Hasil (\%) } \\
\hline Asam lemak bebas & $0,38 \%$ \\
\hline Peroksida & $0,06 \mathrm{meq} / \mathrm{kg}$ \\
\hline Saponifikasi & $\begin{array}{l}252,74 \mathrm{mg} \\
\text { KOH/gram }\end{array}$ \\
\hline Kaprilat $(\mathrm{C} 8)$ & $4,0 \%$ \\
\hline Kaprat $(\mathrm{C} 10)$ & $6,8 \%$ \\
\hline Laurat $(\mathrm{C} 12)$ & $53,2 \%$ \\
\hline Miristat $(\mathrm{C} 14)$ & $19,4 \%$ \\
\hline Palmitat $(\mathrm{C} 16)$ & $8,4 \%$ \\
\hline Stearat $(\mathrm{C} 18)$ & $2,6 \%$ \\
\hline Oleat $(\mathrm{C} 18: 1)$ & $4,6 \%$ \\
\hline Linoleat $(\mathrm{C} 18: 2)$ & $0,8 \%$ \\
\hline Arachidat $(\mathrm{C} 20)$ & $0,1 \%$ \\
\hline
\end{tabular}


Berdasarkan Tabel 1dan Tabel 2 asam lemak bebas (FFA) terbentuk akibat hidrolisis minyak oleh adanya air,asam dan panas yang tinggi. Pembentukan FFA menjadi salah satu parameter kerusakan minyak karena semakin tinggi kadar FFA minyak maka semakin rendah mutu minyak (Mokoginta, 2002).

Proses berlangsung sejak minyak pertama kali diperam yaitu ketika pemisahan krim dan skim. Selanjutnya krim dibiarkan selama 24 jam, guna menurunkan $\mathrm{pH}$ krim agar supaya protein sebagai zat penstabil emulsi dapat rusak hingga pada akhirnya akan terbentuk lapisan minyak, protein dan air. Proses terbentuknya asam ini mempercepat terjadinya hidrolisis gliserida menjadi gliserol dan asam lemak bebas.

Bilangan peroksida merupakan parameter penting yang dapat dijadikan acuan untuk menentukan derajat kerusakan minyak. Peroksida terbentuk karena asam lemak tidak jenuh dapat mengikat oksigen pada ikatan rangkapnya (Ketaren, 1986) yang dikenal dengan proses oksidasi. Proses ini menghasilkan produk oksidasi berupa berbagai senyawa off flavor serta off odor yang disebut sebagai tengik (Fatimah, 2003).

Dari tabel diatas dapat dilihat bahwa nilai rata-rata bilangan peroksida $\mathrm{VCO}$ yang dihasilkan dari VCO (Mustika Palem) nilai terendahnya $0,00 \mathrm{meq} / \mathrm{kg}$ dan $0,06 \mathrm{meq} / \mathrm{kg}$ VCO (buatan). Hal ini berarti bila dibandingkan dengan persyaratan SNI terhadap VCO terhadap nilai maksimum bilangan peroksida yaitu 2,0 meq/kg maka dapat disimpulkan bahwa VCO yang dihasilkan memiliki nilai bilangan peroksida yang baik karena setara dengan nilai bilangan peroksida yang disyaratkan untuk VCO dapat diterima konsumen, kualitas gizinya masih baik dan tidak menimbulkan rekasi yang bersifat toksik (Fatimah, 2003).

Besarnya bilangan penyabunan bergantung dari massa molekul minyak. Minyak yang memiliki berat molekul rendah akan mempunyai bilangan penyabunan yang tinggi. Sebagaimana diketahui bahwa laurat termasuk ke dalam asam lemak rantai sedang dan menyebabkan masa molekul kecil sehingga bilangan penyabunannya pun tinggi yang di tunjukkan dengan nilai bilangan penyabunan pada VCO buatan sendiri yaitu 252,74 $\mathrm{mg} \mathrm{KOH} /$ gram dibandingan dengan VCO merek Palem Mustika yaitu 253,13 mg KOH/gram

Minyak kelapa berdasarkan komposisi asam lemak digolongkan kedalam minyak asam laurat hal ini dikarenakan oleh komposisi asam lauratnya yang paling tinggi bila dibandingkan dengan asam lemak lainnya. Hal ini terlihat jelas pada tabel 1 dan tabel 2 dimana asam lemak dengan nilai tertinggi adalah asam laurat (C12:0) dengan nilai 49,4\% dari VCO (Mustika Palem) dan 53,2\% dari VCO (buatan).

Selain asam laurat ada juga asam myristat $(\mathrm{C} 14: 0)$ yang berada di posisi kedua nilai tertinggi dengan nilai $16,7 \%$ dari VCO (Mustika Palem) dan 19,4\% dari VCO (buatan). Hal ini membuktikan bahwa MCFA seperti asam laurat dan asam myristat adalah asam lemak yang banyak didapat pada minyak kelapa.

Asam kaprat (C10:0) juga merupakan salah satu komponen asam lemak kelapa yang mempunyai fungsi yang menyerupai asam laurat dimana dalam tubuh manusia dan hewan asam kaprat dan asam laurat diubah menjadi monolaurin sedangkan asam kaprat berubah menjadi monokaprin. Senyawa ini termasuk senyawa monogliserida yang bersifat sebagai antivirus, antibakteri dan antibiotik. berperan sebagai antiviral (Sutomo, 2006). Komposisi asam kaprat dalam VCO yang dihasilkan menunjukan nilai berturut-turut 6,4\% dari VCO (Mustika Palem) dan 6,8\% dari VCO (buatan). 


\section{SIMPULAN}

1. Respon peserta yaitu masyarakat di Kelurahan Gedung Johor, Kecamatan Medan Johor, Medan terhadap penyuluhan ini cukup tinggi. Pemahaman masyarakat terhadap manfaat dan kandungan VCO serta cara pembuatan VCO yang benar, sederhana dan murah ini ditanggapi dengan sangat antusias oleh para peserta.

2. Mutu fisik meliputi warna, bau dan rasa yang dihasilkan VCO buatan sendiri dan VCO dari Palm Mustika yaitu normal untuk bau dan rasa serta berwarna putih hingga kuning pucat

3. Mutu kimia VCO buatan sendiri yang didominasi asam laurat yaitu 53,2\% sedangkan VCO dari Mustika Palem yaitu $49,4 \%$. asam lemak bebas (FFA) VCO buatan sendiri yaitu $0,38 \%$ sedangkan asam lemak bebas (FFA) VCO Mustika Palem yaitu $0,08 \%$, bilangan peroksida VCO buatan sendiri yaitu $0,06 \mathrm{meq} / \mathrm{kg}$ sedangkan bilanga peroksida VCO Mustika Palem yaitu $0,00 \mathrm{meq} / \mathrm{kg}$ dan bilangan penyabunan VCO buatan sendiri yaitu 252,74 $\mathrm{mg} \mathrm{KOH} /$ gram sedangkan bilangan penyabunan VCO Mustika Palem yaitu 253,13 mg KOH/gram

\section{UCAPAN TERIMAKASIH}

Ucapan terima kasih diberikan kepada Rektor Universitas Sumatera Utara melalui Lembaga Penelitian Pengabdian Masyarakat (LPPM) Program Profesor Mengabdi Tahun 2020.

\section{DAFTAR PUSTAKA}

[1]. Bawalan, D., \& Chapman, K. (2006). Virgin Coconout Oil Production Manual for Micro and Village-Scale Processing. FAO Regional Office for Asian and The Pacific, 3, 10-12, 15.
[2].Centers for Disease Control and Prevention (CDC). (2020, Maret 04). Retrieved from cdc.gov: https://www.cdc.gov/coronavirus/201 9-ncov/prepare/transmission.html

[3].Fatimah, F., \& Barlina, R. (2011). Pengaruh Diet Emulsi Virgin Coconout Oil terhadap Profil Lipid Tikus Putih (Rattus norvegicus). Jurnal Littri, Volume 17 No.1. ISSN 0853-8212. halaman 18-24.

[4].Ketaren, S. (1986). Pengantar Teknologi Minyak dan Lemak Pangan. Jakarta: Universitas Indonesia (UIPress).

[5].Khopkar, S. (1990). Konsep Dasar Kimia Analitik. Jakarta: Universitas Indonesia.

[6].Mokoginta, Y. (2002). Kajian Beberapa Sifat Mutu Minyak Kelapa yang Diolah Melalui Beberapa Metode Pengolahan secara Basah. Fakultas Pertanian UNSRAT, 26-30.

[7].Nasional, B. S. (2008). SNI 7381: 2008. Minyak Kelapa Virgin Coconout Oil. Jakarta: Badan Standariasi Nasional.

[8].Nasional, B. S. (2009). SNI 662:2009. Penentuan Bilangan Asam. Jakarta: Badan Standarisasi Nasional.

[9].Nasional, B. S. (2012). SNI 3657: 2012. Penentuan Bilangan Penyabunan. Jakarta: Badan Standarisasi Nasional.

[10]. Nasional, B. S. (2017). SNI 3960:2017. Penentuan Bilangan Peroksida. Jakarta: Badan Standarisasi Nasional.

[11]. National Health Committe of The People's Republic of China. (2020, Maret 21). Retrieved from Interpretation of New Coronavirus 
Pneumonia Diagnosis and Treatment

Plant: http://www.nhc.gov.cn

[12]. Pemerintah Kota Medan. (2020, April 29). Retrieved from https://covid19.pemkomedan.go.id

[13]. Sutomo, B. (2006). Informasi Lengkap Mengenai Virgin Coconout Oil (VCO). Jakarta: Gizi dan Kuliner by Rudi.

[14]. World Health Organization (WHO) a. (2020, Maret 23). Retrieved from

https://www.who.int/emergencies/dise ases/novel-coronavirus

2019/technical-guidance/naming-thecoronavirus-disease-(covid-2019)and-the-virus-that-causes-it

[15]. World Health Organization (WHO) b. (2020, Maret 29). Retrieved from

https://www.who.int/newsroom/comm entaries/detail/modes-of-transmissionof-virus-causing- COVID-19implications-for-ipc-precautionrecommendations

[16]. World Health Organization c. (2020, Maret 23). Retrieved from https://www.who.int/dg/speeches/deta il/who-director-general-s-opening remarks-at-the-media-briefing-on COVID-19 